\title{
CAMPTODACTYLY AND KIRNER'S DEFORMITY IN ONE FAMILY
}

\author{
BiR AILEDEKI KAMPTODAKTILI VE KIRNER DEFORMITESI
}

\author{
Mehmet ERDURAN ${ }^{1}$ Jülide ALTINIŞIK ${ }^{2}$ Gökhan MERiç ${ }^{3}$ Ali Engin ULUSAL ${ }^{3}$ Devrim AKSEKi ${ }^{3}$
}

${ }^{1}$ Dokuz Eylül Üniversitesi Tıp Fakültesi
Ortopedi Ve Travmatoloji Anabilim
Dalı,Izmir, ${ }^{2}$ Balıkesir Üniversitesi Tıp
Fakültesi Tıbbi Biyoloji Anabilim Dalı,
${ }^{3}$ Balıkesir Üniversitesi Tıp Fakültesi Ortopedi
Ve Travmatoloji Anabilim Dalı, Balıkesir

Yazışma Adresi:

Mehmet ERDURAN

Dokuz Eylül Üniversitesi Tıp Fakültesi

Ortopedi ve Travmatoloji Anabilim Dalı İzmir Türkiye

E posta: dr.erduran@hotmail.com

Kabul Tarihi: 16 Mart 2013

Balıkesir Sağlık Bilimleri Dergisi

ISSN: 2146-9601

e-ISSN: 2147-2238

bsbd@balikesir.edu.tr www.bau-sbdergisi.com

\section{ÖZET}

Kirner deformitesi ve kamptodaktili elin nadir görülen konjenital deformiteleridir ve genellikle bağımsız anomaliler olarak görülmektedir. Kirner deformitesi 5.parmak parmak distal falanksının değişik derecelerde palmar ve radial deviasyonu ile karakterizedir ve distal interfalangeal eklemde şişlik ve 5. parmak tırnağında dismorfik değişikliklerle birlikte görülür. Kamptodaktili bir parmak deformitesidir ve bir ya da birçok parmağın proksimal interfalangeal ekleminin travma olmaksızın fleksiyon kontraktürü ve buna bağlı etkilenen parmaklarda volar eğim ile karakterizedir. Tüm parmaklar etkilenebilmesine rağmen en sık 5. parmak etkilenir. Bu iki hastalığın kombinasyonuna sahip bir aile daha önce rapor edilmedi. Bu yazımızda kirner deformitesi ve kamptodaktili'nin ortak bir genetik faktöre sahip olabileceği ön görülen bir aile sunuduk.

Anahtar Kelimeler: Kamptodaktili, Kirner deformitesi, genetik geçis

\section{SUMMARY}

Kirner's deformity and camptodactyly are rare congenital hand deformities usually occurring independently. Kirner's deformity is characterized by palmar and radial deviation of the distal phalanx of the little finger with a varying degree of rotation and a small, dysmorphic watchglass nail associated with swelling of the distal interphalangeal joint. Camptodactyly is a nontraumatic flexion contracture of the proximal interphalangeal joints of one or more fingers, resulting in a permanent volar inclination of the affected digits. Little finger is the most frequently affected one, but additional fingers may also be involved. The combination of these two entities in a family had not been previously reported. The family presented here suggests that Kirner's deformity and camptodactyly may have a common genetic factor.

Key words: Kamptodactyly, Kirner's deformity, genetic transmission

\section{Introduction}

Kirner's deformity and camptodactyly are rare and usually bilaterally occurring congenital hand deformities 1-3. Kirner's deformity is characterized by palmar and radial deviation of the distal phalanx of the little finger with a varying degree of rotation and a small, dysmorphic watch-glass nail associated with swelling of the distal interphalangeal (DIP) joint. The deformity usually becomes obvious between the ages of eight and fourteen years, and twice as commonly in females. It can be progressive and sometimes is associated with swelling and redness at the base of the nail, but it is rarely painful. Kirner's deformity is suggested to be inherited in an autosomal dominant trait with incomplete penetrance but sporadic cases were also reported. No specific genetic linkage has been identified ${ }^{1,2,4}$. Camptodactyly is a non-traumatic flexion contracture of the proximal interphalangeal (PIP) joints of one or more fingers, resulting in a permanent volar inclination of the affected digits. Little finger is the most frequently affected one, but additional fingers may also be involved. The degree of flexion varies from very mild to almost right-angled bend and may progress during adolescent growth period or remain unchanged for years. Camptodactyly may be sporadic or familial. In severe forms, flexion contractions are usually seen in multiple digits of both hands and this form is associated with other congenital anomalies such as chromosomal disorders, craniofacial diseases and 
skeletal deformities ${ }^{5}$. In isolated camptodactyly, one or both little fingers are affected and this form is inherited in autosomal dominant trait with variable penetrance or expressivity, or it may be sporadic ${ }^{5,6}$. Knuckle pads upon the PIP joints might also be observed in combination with isolated camptodactyly ${ }^{7}$.

The combination of these two entities in a family had not been previously reported. The family presented here suggests that Kirner's deformity and camptodactyly may have a common genetic factor.

\section{Report of the Case}

A 14 year old girl presented to our clinic with a history of swelling and increasing deformity of the distal phalanx of her little fingers. The deformity has existed for 3 years. The patient had no pain but had some discomfort when typing. There was no history of trauma and infection. Physical examination confirmed palmar and radial deviation of distal phalanges of both little fingers, but the right side was the most affected one (Fig 1).

Figure 1. Radial and palmar deviation of the distal phalanx of little fingers.

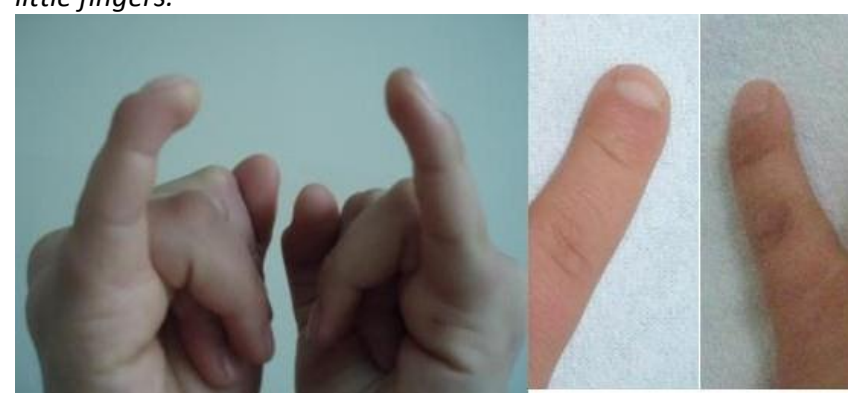

Figure 2. AP view (a) and lateral view (b) of right and left little fingers.
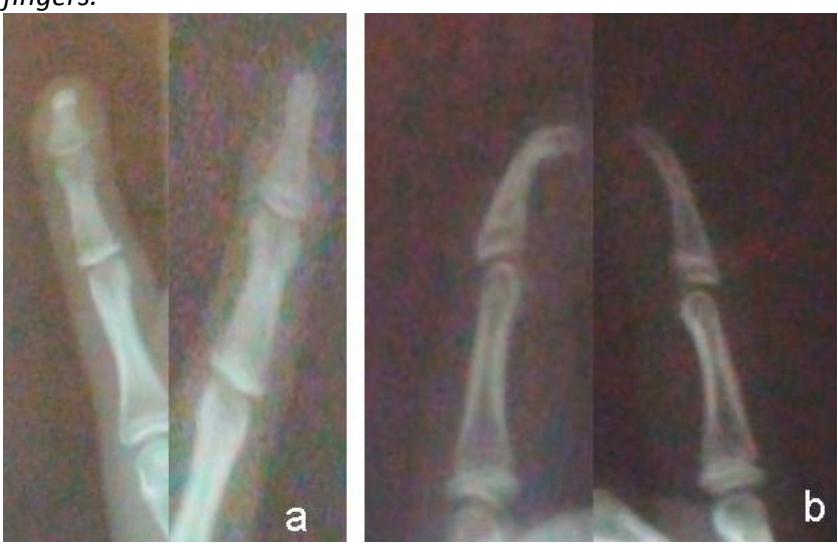

The nails were also curved in volar direction. The flexor and extensor mechanisms functioned normally. Her routine blood examinations were normal and rheumatoid factor was negative. On radiographies, the head of the distal phalanges of little fingers showed a pronounced tilting in both volar and more slightly in the radial direction, with preservation of the epiphyseal, metaphyseal and articular alignment (Fig 2). This deviation was recognized as being Kirner's deformity. The family history revealed that there were no any relatives having this deformity but there were 2 people having camptodactyly in various degrees in father's family (Fig 3).

Figure 3. Pedigree of patient's family

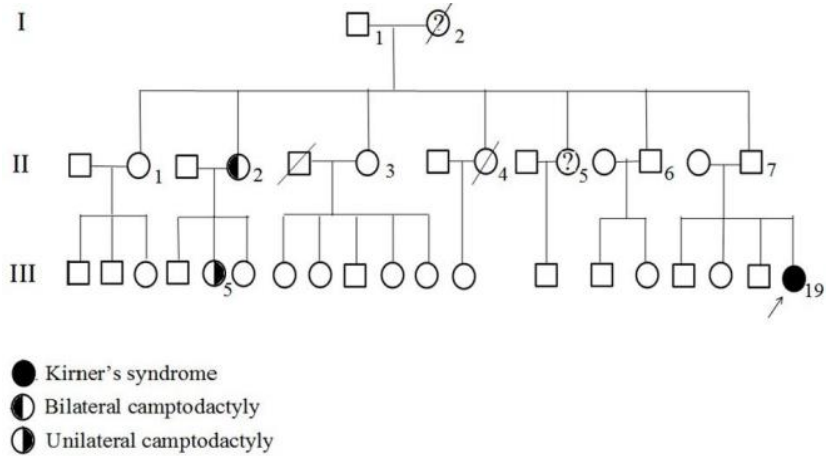

Figure 4. Radiograph of both hands and photograph of right and left hand of the case II.2 (A)

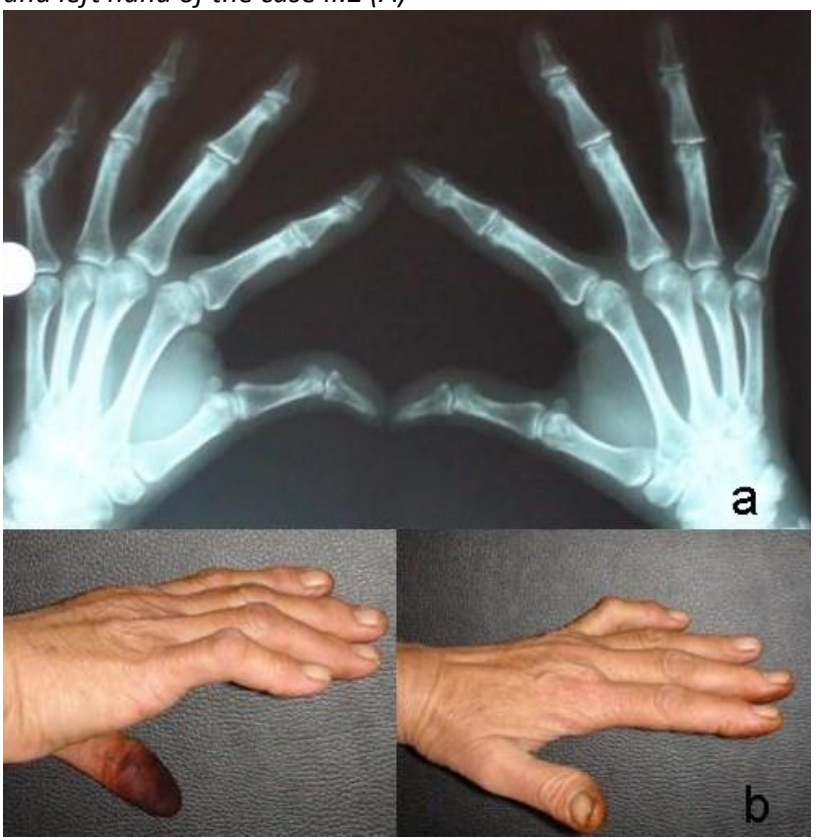


The patient's aunt (casell.2) had bilateral camptodactyly in her both little fingers (Fig 4) and had knuckle pads on PIP joints of all fingers except the thumbs (Fig 5). Her daughter (case III.5) had unilateral camptodactyly in only right little finger in a mild degree (Fig 6), and had knuckle pads on all fingers except thumbs. The patient said that paternal grandmother (case I.2) who was not alive and one aunt (case II.5) had also been affected but they have not been examined to confirm this.

Figure 5. Knuckle pads of case II.2

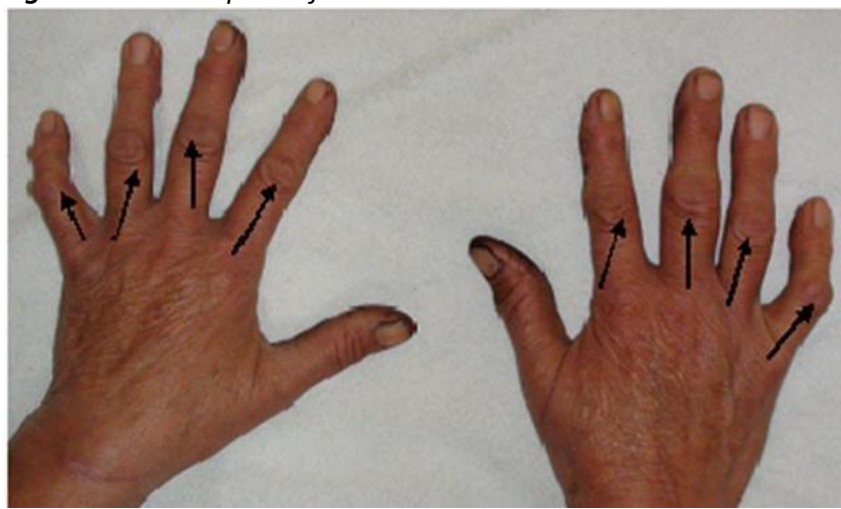

Figure 6. Unilateral camptodactyly of case III.5

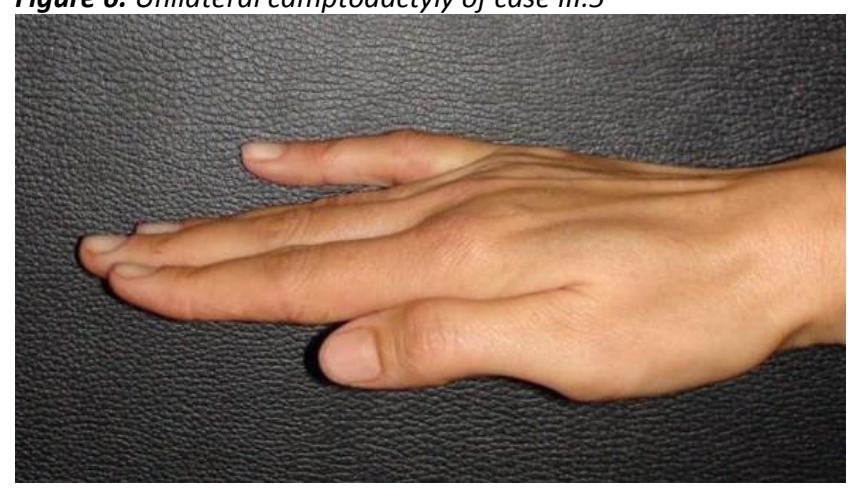

\section{Discussion}

Kirner's deformity and camptodactyly have been regarded as independent congenital hand deformities ${ }^{1-3}$. They both may be sporadic or familial ${ }^{1,2,5,6,8}$. In inherited forms of Kirner's deformity, it is an independent anomaly, but it can also occur as a minor part of different syndromes such as Down syndrome, pes cavus, osteomyelitis, and progressive myositis ossificans ${ }^{2}$. The etiology of Kirner's syndrome is not well understood. Kaufmann et al. suggested a lysis between diaphysis and epiphysis of the terminal phalanx ${ }^{10}$. Several other factors as a developmental defect in enchondral ossification, an osteochondrosis possibly of vascular origin or of unknown origin ${ }^{9}$ have been suggested.

Some familial cases of Kirner's deformity ${ }^{1,8}$ and cases without a family history ${ }^{2}$ have been reported. Damen et al. reported a patient with Kirner's syndrome and 7 clinodactyly cases in a family. He suggested that there could be a common genetic factor for Kirner's deformity and clinodactyly ${ }^{9}$. There is no any report about the association of Kirner's deformity and camptodactyly.

Camptodactyly may occur as an isolated deformity as well as a part of many well-characterized hereditary syndromes. Isolated type can be sporadic or can have an autosomal dominant trait with variable penetrance and expressivity. The first locus of 5th finger of camptodactyly was mapped to 3q11.2-q13.12 in a large German family by Malik et al. and was reported that this locus was not shared by any other camptodactyly-like syndrome ${ }^{7}$. The gene for this deformity has not been identified as well as any specific gene locus and gene has not been reported for Kirner's deformity.

We here present a family with one case of Kirner's deformity and 2 cases with camptodactyly and 2 probable camptodactyly cases who were not examined. The presence of both camptodactyly and Kirner's deformity in this family suggest that there could be a genetic linkage between these deformities or they could be different expressions of a common genetic disorder. As Kirner's deformity has not been mapped to any chromosomal location, the gene responsible for this syndrome may also be located in the chromosomal locus of camptodactyly (CAMPD1). Experimental studies should be performed in families in order to define the locus and gene of Kirner's deformity.

\section{REFERENCES}

1. Song WC, Koh KS. Kirner's deformity: progressiveness and classification (Surg Radiol Anat) 2005; 27:459-62

2. Scott CE, Engber W. Kirner's deformity: A case report and review (lowa Orthop J) 1996; 16:167-9

3. Flatt AE. The troubles with pinkies (BUMC Proceedings) 2005; 18:341-4

4. Beluffi G, Fiori P. Clinical and radiological findings in Kirner's deformity. A report of nine cases. (Radiol Med) 2006; 111:432-9 
5. Ty JM, James MA. Failure of Differentiation: Part II (Arthrogryposis, Camptodactyly, Clinodactyly, Madelung Deformity, Trigger Finger and Trigger Thumb). Hand Clinic 25,2009:195-213. Elsevier Inc.

6. Malik S, Afzal M, Gul S, Wahab A, Ahmad M. Autosomal Dominant Syndrome of Camptodactyly, Clinodactyly, Syndactyly and Bifid Toes (Am J Med Genet) 2010; 152:2313-7.

7. Malik S, Schott J, Schiller J, Junge A, Baum E, Koch MC. Fifth finger camptodactyly maps to chromosome 3q11.2-q13.12 in a large German kindred (Eur J Hum Genet) 2008; 16:265-9.

8. David TJ, Burwood RL. The nature and inheritance of Kirner's deformity (J Med Genet) 1972; 9:430-3.

9. Damen A, Lei B, Nicolai JPA. Kirner's deformity and clinodactyly in one family (Eur J Plas Surg) 2000; 23:235-7.

10. Kaufmann HJ, Taillard WF. Bilateral incurving of the terminal phalanges of the fifth fingers (Am J Roentgenol) 1961; 86:490 